\section{President Barack Obama's Policy Choices in NATO Rhetoric}

\author{
Marta Rzepecka \\ University of Rzeszow, Poland \\ https://orcid.org/0000-0002-0355-790X
}

Political Preferences

2019, vol. 25: 21-36

journals.us.edu.pl/index.php/PP Submitted: 03/04/2019

Accepted: 22/12/2019

\begin{abstract}
:
This article uses Michael C. McGee's concept of the ideograph to reflect Obama's early foreign policy course regarding transatlantic relations. Specifically, the article draws on the ideograph "alliance" to demonstrate how the president redefined agents, acts, agencies, scenes, and purposes that fall within the rhetoric, thus informing how and why he changed US commitment to NATO. Analyzing Obama's use of alliance serves to interpret his political choices as well as understand his ability to get the public to support them. By extension, a study of this nature offers a reading of the president's perspective on US foreign policy and America's global role.
\end{abstract}

Keywords: NATO, alliance, ideograph, Barack Obama, foreign policy

\title{
Introduction
}

An examination of relations between the United States and Europe during the first months of Barack Obama's presidency should begin with a discussion of the foreign policy legacy of President George W. Bush. For it is the policies of the Bush administration that isolated the US from Europe and thus shaped Obama's early approach towards the transatlantic alliance. Among the most commonly quoted sources of the drift is the US strategic orientation (Kupchan 2012; Hodge 2010; Rielly 2008). Scholars find that the challenge of contemporary terrorism in the aftermath of the September 11, 2001, attacks predisposed the Bush administration to choose unilateralism and preemption over multilateral policymaking. The invasion of Iraq in 2003 is invoked as the most telling example of America's one-sided action. The US took combat operations in Iraq ignoring Europe's arguments that the use of force was excessive and military action was counterproductive, fueling instability, tensions, and divisions in the region instead of 
eliminating them. Amid the rift over Iraq, the discord between the US and Europe concerned the US withdrawal from the Anti-Ballistic Missile Treaty negotiated in 1972 between the US and the Soviet Union regarding the superpowers' strategic capabilities (Bush 2001b). The US justified the termination of the treaty with circumstances compelling it to develop a national missile defense system against possible terrorist ballistic missile attacks. Moreover, during the Bush years, the US ended its participation in the formation of the International Criminal Court (ICC), launching a campaign against the Court to weaken its authority and undermine its legitimacy (Heindel 2004). Core concerns raised by Washington against the Court included fear of political prosecution and infringement of US sovereignty as well as concerns over the Court's accountability and standards. The US also refused to ratify the Kyoto Protocol on global warming and prevented the agreement on emission control to go into effect (Bush 2001a). The decision was defended on the ground that the terms of the Protocol seriously harmed the US economy and failed to address the problem of global climate change effectively. Finally, the US opposed the Comprehensive Test Ban Treaty, one that regards the obligation of the parties not to carry out any nuclear explosion, while supporting the continuation of the US nuclear testing moratorium (CTBT Report).

Strained transatlantic relations posed a major challenge for Bush's successor. In confronting the task of how to restore Europe's confidence in the US commitment to multilateralism and global leadership, Barack Obama ran his presidential campaign on a pledge to end the war in Iraq (Obama 2007), cut investment in missile defense systems (Obama 2008b), and eliminate nuclear weapons. He declared to reverse the Bush administration's course taken for the ICC and to begin cooperating with its leaders and staff (Feinstein \& Lindberg 2009). He ensured that America would renew the Kyoto Protocol treaty and work with the international community on a constructive response to the threat of climate change (Obama 2008a). When he took office, he scheduled his first overseas trip to Europe, beginning with a visit to England, where he attended the G-20 summit, continuing his travel to France and Germany, where he participated in the NATO summit, to the Czech Republic, where he took part in the US-EU summit meeting, and concluding his tour in Turkey. The goals of the G-20, the NATO, and the US-UE summit meetings aside, the overarching objective of the president's trip was to demonstrate his administration's resolve to set the US on a new course in its relations with Europe and project a clear vision and direction for America's leadership in world affairs. International trips have long been recognized as strategic means to an end for presidential foreign 
policymaking (Weitsman 2004). First state visits and international summits have been suggested to be an important element of US administrations' efforts to form, maintain, strengthen and/or restore foreign relations; and presidential communication with foreign partners has been considered as being central to positive outcomes of such undertakings.

\section{Obama's Policy Choices and Public Opinion}

What priority did Americans and Europeans place on Obama's foreign policy and what expectations did they hold for the president in the realm of transatlantic relations? As June 2008 surveys carried out by The German Marshall Fund of the United States and Pew Research Center showed, Americans and Europeans overall agreed that international terrorism and international economic problems should be the top priorities for the next American president, that global issues should be addressed in partnership rather than independently, and that Europeans and Americans had enough common values to cooperate on common problems. A majority of Americans and Europeans also agreed that NATO was essential for their countries' security, that all NATO countries should contribute troops to NATO military actions and share the financial costs of NATO combat missions.

Looking at the American and European publics' expectations, 69 percent of Europeans favored Obama and 47 percent believed that US relations with Europe would improve after his inauguration. Europeans were not only optimistic about a post-George W. Bush era American foreign policy, but were clearly excited about the prospects for an Obama-led US foreign policy. 84 percent of the French, 82 percent of the Germans and 74 percent of the British expressed strong confidence in Obama and his performance in world affairs. Among Americans who viewed Obama favorably, 48 percent thought that US-European relations had gotten worse in the previous year and 56 percent hoped that the partnership in security and diplomatic relations with Europe would become closer.

However, specific policy preferences of the European public presented a major challenge for the president's political course. On the question of policy options in Afghanistan, a majority of Europeans opposed conducting combat operations (57 percent) and disagreed with the statement that "under some conditions war was necessary to obtain justice" (71 percent). Support was shown for non-combat options, such as providing security for economic reconstruction (79 percent), assisting with military training (68 percent), and combating narcotics production (76 
percent). On the issue of troop commitment to US and NATO mission in Afghanistan, Europeans were either divided (43 percent of the British remove troops vs. 48 percent keep troops) or favored removing troops (54 percent of the French and the Germans). The president's attempts to address economic issues were also likely to be challenged, considering that over 70 percent of the British, the French, and the Germans viewed the impact of the US economy on their country's economy to be negative.

In the aftermath of the 2008 presidential elections, European and American public continued to hold great expectations for President Obama. Extraordinary high assessment of the president after he entered the White House in early 2009 was a reflection of those hopes. The Pew Research Center's Global Attitudes Project, conducted in April 2009, found that Europeans' overall opinion of Barack Obama remained very positive ( 88 percent in Germany, 84 percent in France, and 64 percent in Britain). Data collected from Gallup polls on presidential job approval between January and March 2009 showed that satisfaction with the president's job performance was also high at home, within 67 and 59 percent. According to a CBS News poll administered between February and April 2009, a majority of Americans agreed that Obama shared their priorities for the country (65 percent) and approved of the way he was handling foreign policy (50-59 percent) and economy (55-56 percent). Such context clearly provided very high support for Obama on his first state visit overseas thus generating a unique opportunity for the president to use his popularity to influence and handle opposition to his policy choices.

\section{Ideographic Analysis}

The analysis of how President Obama communicated his approach to the issue of the transatlantic alliance is informed by Michael C. McGee's (1990: 341-343) concept of the ideograph. McGee defines the ideograph as "an ordinary language term found in political discourse ... a high-order abstraction representing collective commitment to a particular but equivocal and ill-defined normative goal." For McGee, the ideograph "warrants the use of power, excuses behavior and belief which might otherwise be perceived as eccentric or antisocial, and guides behavior and belief into channels easily recognized as acceptable and laudable." It is "culture-bound" and is "always understood in its relation to another." The ideographs are structured in two ways: diachronically, that is "in isolation . . such that current meanings of the term are linked to past usage of it" and synchronically as "together . . . thought at any specific 
"moment" to be consonant, related one to another in such a way as to produce unity of commitment in a particular historical context."

McGee's notion of the ideograph has been used as a lens to critique different rhetorical subjects from both of the above structural perspectives. It has been used in the study of identities, agenda, and practices of niche groups (Bennett-Carpenter 2009), memetics (Johnson 2007), corporate rhetoric (Amernic \& Craig 2004), marriage discourse (Grindstaff 2003), religious reform movement (Jasinski 2002), rail communication (Coogan 2002), Castroism (Delgado 1999), depictive rhetoric (Edwards \& Winkler 1997), Chicano movement rhetoric (Delgado 1995), midwifery debate (Miller 1999), and constitutive rhetoric of state sovereignty (Charland 1987). Research has discussed the questions regarding how ideographs constructed public issues, shaped political debate, and encouraged collective commitment to restrictive action (Kuypers \& Althouse 2009; Parry-Giles 1995). It has asked specifically how the ideograph of terrorism affected general US foreign policy principles and specific US foreign policy decisions and actions (Long 2013; Winkler 2006; Valenzano III 2006), how the ideograph of patriotic changed the understanding of a patriotic American during times of war (Towner 2010), how the ideograph of victim directed a discussion of the death penalty in Illinois in 2003 (McCann 2007), how nonverbal representations of the ideographs of woman and man influenced the woman suffrage (Palczewski 2005), how the ideograph of family values structured the problems of poverty and racism in the 1992 presidential general election campaign (Cloud 1998), how the ideograph of equality reflected the understanding of legal practices (Hasian et al. 1996), and how the meaning of the ideograph shifted over time in the process of negotiation among different social groups (Condit \& Lucaites 1993).Clearly, the scope of the discussion regarding ideographs is widespread amongst disciplines and can be used to further investigate the impact of presidential rhetoric.

As part of the discussion, this study asks how the ideograph of alliance shaped President Obama's foreign policy course and discourse at the onset of his presidency. It analyzes the ideograph within presidential rhetoric to explain how and why the president changed US commitment to this international partnership. Obama challenged both the Cold War and postCold War model of the alliance, looking for a transformation of the partnership from a relationship focused on Europe's needs and wants to one attuned similarly to America's interest. Analyzing Obama's definition of alliance, its setting, the means of its protection, and the reason for its continuation can be helpful in interpreting his political talk and the consequent action. 
Moreover, examining the president's appropriation of the ideograph of alliance can help to understand his ability to get the public to accept and support his less popular policies. By extension, a study of this nature offers reading of the administration's perspective on foreign policy and America's role in the world as it is shaped by the president and his policies' long-term consequences. This study performs a textual analysis of statements made by Obama during his first state visit to Europe. First, a term search for the word alliance was conducted across all presidential statements made during the trip. Second, the obtained data set was narrowed to the statements which focused on the issue of the transatlantic alliance. Third, the selected statements were examined synchronically to describe the use of the ideograph and its relation to others within a particular historical context and at a particular point in time.

\section{Alliance as Ideograph}

The analysis of the ideograph of alliance within President Obama's rhetoric should begin with a brief commentary on the characteristics of the ideograph to demonstrate that alliance falls into the definition. First, the term meets the criteria of operating "clearly and evidently as [an agent] of political consciousness" and as "a part of the real lives of the people whose motives [it articulates]" (McGee 1990: 335). It exists in real public discourse and is easily encountered in the media, in politics, and in scholarship (Lee 2009: 295). Its impact on domestic politics only increases the likelihood of its usage in citizen political conversations (Winkler 2006: 12). Second, alliance represents functions that "unite and separate human beings" (McGee 1990: 336-337). It defines "a collectivity" and differs "in its meanings or its usage" among societies. Alliance is transcendent in character, broad in appeal, and flexible in interpretation (Winkler 2006: 13). It carries little cognitive meaning and much emotional affect. It is used to make judgments and represents something to be achieved (Lee 2009: 295). Third, alliance justifies the exercise of power (Lee 2009: 295). It rationalizes leaders' decisions and actions which negotiate historically and socially acceptable norms and values (Winkler 2006: 14). Fourth, alliance is "descriptive of an essentially social human condition" (McGee 1990: 337). It is a defining feature of a tradition and carries a culture-specific significance (Lee 2009: 295). Consent to or defiance of its interpretation determines one's membership within the society (Winkler 2006: 14).

When President Obama talks about alliance during his first foreign trip, he refers to the relationship created among members of the North Atlantic Treaty Organization (NATO). 
Recognizing the damaging impact of President Bush's foreign policy discourse on allied relations, Obama establishes his own rhetoric of the alliance, redefining agents, acts, agencies, scenes, and purposes that fall within it, and thus shifting the discourse to one that sought to work with and within the partnership.

Strategic to the president's rhetoric of alliance are the agents. These include America and Europe, especially the United Kingdom, France, and Germany. Across the discourse, the agents are described through the lens of 60 years of shared history (Obama 2009e, 2009g). The US is referred to as the agent who over the years has protected Europe and has guaranteed security in Europe while Europe is referred to as the agent whose concerns have been central to US foreign policy and whose opinions on major issues have mattered and have been respected. This perspective of legacy is contrasted with an approach which repositions the agents and reformulates the relationship between them. Europe is as strategic to the alliance as America and qualities of European countries are recognized and admired much as American values (Obama 2009e). Admitting one's mistakes, accepting others' arguments, and seeking compromise applies to all allies, including the US (Obama 2009e). Similarly, looking for solutions, responding to global challenges, and sharing the burden of the response fall within each ally's commitment, including Europe's (Obama 2009a). The alliance which so far has been understood as a forum dominated and led by the US is challenged to become an agency for a partnership of equals with shared benefits and responsibilities.

Fundamental to the task is reform, or in Obama's campaign language, change. The first one is that of attitude. America's arrogance, disregard, and scorn for its partners have to be replaced with acknowledgment and appreciation for their union and global role (Obama 2009a). Likewise, Europe's stance against Americanism, and critique and blame placed on American policies, has to make way for recognition of the good that these policies have done in the world (Obama 2009a). The second change is that of structure. The roles and responsibilities of the alliance must be defined and adjusted to the 21st century (Obama 2009f). A framework which has been successful at meeting the challenges of the Cold War should now be renewed to meet the demands of the post-Cold War and post-American world order. The third change concerns military capabilities and involves improving planning, modernizing the military, and strengthening Europe's defense. European countries are expected to rise above the challenge of ensuring mutual security and increase their commitment to allied military budget, take a lead in 


\section{Marta Rzepecka}

the alliance's military operations, and manage conflicts and handle their consequences independently of the US (Obama 2009a). The fourth change relates to Afghanistan. The US needs to commit itself to review its approach to the war and balance military solutions against nonmilitary assistance, including aid, development, and diplomacy. But Europe also needs to rethink its own attitude toward the conflict and accept its military component by making a more meaningful contribution to ensuring security in the region (Obama 2009a). The final change applies to the alliance's relationship with Russia. Allies should work on a strategy for connecting the major global actors who act in concert not in opposition (Obama 2009g).

Now, there has not been one means to implement the changes. Instead, a series of steps have been suggested to push the reform through. Crucial to it has been the US attitude. Washington has declared to give up on always being right and having the best answers and has committed itself to show humility and respect for others (Obama 2009d). It has expressed the determination to take a new approach in its foreign policy, one in which listening is valued over speaking, learning over lecturing, and helping to shape the vision for the future over dictating solutions (Obama 2009d, 2009h). America has also come to understand that alliance presupposes concerted effort and that only unanimous decisions and collective action can ensure a common way forward (Obama 2009d, 2009e, 2009f). Likewise, Europe must realize that the era of acting alone and/or on behalf of others is over and allies cannot wait for the action of other partners but should take the initiative or equally contribute to the cause (Obama 2009a). Emphasis is placed on the values that bring allies closer together rather than on the differences that widen the divide between them; faith instead of resentment towards each other; compromise and cooperation on difficult issues rather than surrender to the problems that can leave allies only more isolated (Obama 2009a). The alliance is portrayed as an institution which has the potential to reinvent itself and allies as agents who are able to re-establish their relationship. A sense of enthusiasm is balanced against a sense of caution. It is recognized that allies will continue to have separate interests, negotiations will be difficult, disagreements will be unavoidable, and agreements will not always be achievable (Obama 2009d). The hope of seeing the alliance stronger and more productive is accompanied by the awareness that changes in attitude, structure, capabilities, and relations will neither come quickly nor easily (Obama 2009d).

NATO's mission in Afghanistan especially exemplifies this framework. Afghanistan serves as a scene for alliance and contextualizes the argumentation for NATO's reform, justifying 
the steps and means needed to be taken to renew the relationship. The mission marks NATO's first operation taken beyond the borders of Europe and is described as a complex and difficult task with a lot of facets to it (Obama 2009f). Allies' contribution to Afghanistan is a measure of the alliance's way forward as it exposes their obligations and commitment to meet them (Obama 2009f, 2009g). It is also a test case for the partnership between the countries because it demonstrates how well allies can work together to achieve a common objective for a common cause (Obama 2009e, 2009f). NATO's engagement in Afghanistan checks allies' understanding of the purpose of the mission as much as the seriousness of purpose with which they approach NATO itself. It verifies whether declared principles of consensus and unity remain merely conference pledges or whether they apply to concrete practical action (Obama 2009e). In a broader perspective, NATO's renewed engagement in Afghanistan marks the end of irresponsible foreign policymaking and the beginning of responsible decisions. It no longer defines the US as a uniquely qualified ally to lead the mission; rather, it indicates Americans' preference for working through multilateral frameworks which proportionally engage all allies. Moreover, the mission is the point of departure for argumentation for extension of the operations in the region. It is used to persuade allies to also invest their resources into Pakistan and India (Obama 2009g). From this perspective, the mission in Afghanistan serves as one operation to shape interpretation of others. It represents a small scene taking place in a larger context.

Afghanistan is also the primary purpose of action. It works as the most immediate reason why NATO should make efforts to reform its structures and renew the relationship amongst the allies. A point made about NATO's mission in Afghanistan whose goal there is not to occupy or run the country but to provide it with the capacity to ensure its own security directly translates into Obama's sentiment about the United States' renewed role in NATO (Obama 2009f). According to it, America is part of the alliance not to dominate or lead it but, while continuing to provide the unique assets that only the US possesses, it is there to assist other allies in enhancing their military capabilities to become fuller and stronger partners. Moreover, a higher purpose is present. It is to combat fear and want, to guarantee peace and prosperity (Obama 2009a, 2009g). Despite these perpetual intentions of the alliance, the circumstances have changed with respect to the scope and means of their realization. The alliance's focus on the needs of and dangers in Europe has been redirected to the concerns of and threats around the world. Finally, there might be a personal reason for action. The fact that Obama is seen as the president who chooses to focus 
on the Pacific region does not mean that Atlantic integration matters less to him. Turning NATO into an organization able to confront the challenges of the post-Cold War and post-American world order and rebalancing allied relations into productive cooperation would be a meaningful and lasting legacy of every president, including Obama. A notable profile of Europe in the president's administration's early official rhetoric and agenda might be read as a sign of such aspiration.

\section{Alliances as Means to Security}

President Obama's primary concern with continuing this alliance for the purpose of common security is to strengthen it by improving allied capabilities and renewing allied commitments. His sense of allied relations is built on the existence of a strong military, specifically on shared military responsibilities. Obama believes that the alliance will be able to repel an attack of an enemy if all allies are more capable defensively. Reading into the president's rhetoric of the alliance, there does not seem to be an alternative. Failing to improve strategic capabilities means failing to deliver on the core principle of the alliance that ensures mutual responsibility to common security.

To demonstrate the need for greater contribution to the partnership, Obama talks about past and ongoing terrorist activity. He recalls that terrorists have struck in both Europe and America and warns that "Al Qaida trains, plots, and threatens to launch their next attack" (Obama 2009i). He speculates that the "attack could occur in any nation," though "it is probably more likely that Al Qaida would be able to launch a serious terrorist attack in Europe than in the United States because of proximity" (Obama 2009g). Invoking the past and predicting future security threats, Obama strikes at the heart of the alliance. Transatlantic security defines the identity and mission of the partnership. It preserves and maintains the relationship among allies. Falling short of fulfilling one's responsibilities puts other partners at risk.

Directing attention to a tangible threat to the security of the allies, which consequently implies a weak alliance, is rhetorically effective in ensuring that the allies unite and feel empowered under a common threat. Obama suggests that force that has been driving partners apart can be used to ensure that their actions are unified and lead directly to the same outcome. Doubt that has accompanied the questions of war on terror can be turned into mutual reliance and trust in each other's concern about common peace and prosperity. Isolation can help allies reconvince themselves of the principle that "Europe's security [is] the United States security and 
vice versa" (Obama 2009g) to the commitment that "An attack on one [ally is] viewed as an attack on all" (Obama 2009a).

Dealing with the problems involved in the mission in Afghanistan is a means to achieve the goal. Obama recognizes that "When 9/11 happened, Europe responded as a true friend would respond to the United States, saying, 'We are all Americans'" (Obama 2009a). He praises France for its leadership and understanding regarding the mission. He honors the British and German troops and governments for their service and resources. In appreciating Europe's role in Afghanistan, the president tries to countermeasure some of the failures of the Bush administration. His words of thanks are an attempt to revive in allies the feeling of identity and belonging, re-inspire in them the sense of commitment, and encourage them to rally again around a shared vision of their way forward.

For this purpose, he grounds the vision in the alliance's core values, which he describes as antithetical to those of terrorists'. Obama states that terrorist "organizations are willing to kill innocent people because of a twisted, distorted ideology. And we as democracies and as people who value human life can't allow those organizations to operate" (Obama 2009a). The core values of the alliance are the foundation of the partnership's identity and its cause. They define its philosophy and system as superior to those represented by the enemy. The values contain an obligation for allies to prevent vicious and evil acts and hence guarantee that allied action is humane and good. Moreover, they imply that the action is morally justified, regardless of the means taken to carry it out. The injustice to be righted serves to rationalize the extent of violence.

A similar line of thinking applies when Obama persuades Europe to strengthen its commitment to the alliance's military structures. He makes a point that during and after the Cold War it was precisely the US military power that ensured the continent's recovery and stability. The president remarks that "we take this peace and prosperity for granted, but this destination was not easily reached, nor was it predestined. The buildings that are now living monuments to European union - unity were not drawn from simple blueprints. They were born out of the blood" (Obama 2009a). In the stated message, Obama leads Europe to a sense of obligation. He summons it to translate its intentions into action, to stop making excuses and participate in joint efforts. The implied message is that time has now come to pay one's duty to the alliance. Europe needs to accept that the partnership's activity extends beyond the continent's borders and its leaders' tactics in solving problems so far. 


\section{Marta Rzepecka}

\section{Credibility as Means to Alliance}

Building credibility for the argumentation for a stronger alliance, Obama recalls the September 11, 2001, attacks. He stresses that "The United States of America did not choose to fight a war in Afghanistan" (Obama 2009a) and reminds that "We were attacked by an Al Qaida network." He continues to emphasize that in the attacks an Al Qaida network "killed thousands on American soil, including French and Germans." His discourse is powerful because it imposes an interpretation that is difficult to disagree with. It calls the enemy's attack a deliberative offensive and defines allied use of force a matter of necessity. It casts the alliance in the role of a guardian of peace, a defender of freedom, and a warrior on the righteous side in the struggle between the forces of good and evil. It legitimizes its actions in the name of protection of nations and territories as well as their systems of governments, religious beliefs, and civic values.

Speaking about the problems of the partnership instead of closing eyes and pretending that they do not exist also gives the president the credibility to act. Obama openly admits that "Nowhere have we seen more suspicion than around questions of war and peace and how we respond to terrorism" (Obama 2009a). By acknowledging that America deserves part of the responsibility for the difficulties within the alliance, he communicates the will to rebuild partners' trust and confidence in the US' readiness to act together for common purpose. Saying without equivocation that "we must be honest with ourselves" (Obama 2009a) and "that there's something more that has crept into our relationship" conveys his determination to get to the root of the problem rather than merely state that it is there. Behind these words lies a rare shift in the US presidents' approach to foreign policy making. Although only three months into his first term, Obama makes remarks that may not sound particularly radical but are an isolated case of a sitting US president trying to reverse the trend that asserted America is always right while admitting his country's fallibility.

The way Obama uses the concept of American exceptionalism is also relevant in the discussion of legitimizing his approach towards the alliance. In the treatment of the concept, the president explains that "the fact that I am very proud of my country . . . does not lessen my interest in recognizing the value and wonderful qualities of other countries" (Obama 2009e). He thinks that "we have a core set of values ... that, though imperfect, are exceptional" (Obama 2009e). He sees "no contradiction between believing that America has a continued extraordinary role in leading the world ... and recognizing that that leadership ... depends on, [the US] ability to create partnerships" (Obama 2009e). While there may be no contradiction, the choice of the 
model of America's activism in the alliance that Obama favors is ambiguous at least. The use of the concept suggests that the president wants room for maneuver and justification of less popular policy stances and practices. He demonstrates support for active policy and multilateral approach but also signals his approval for US' limited international role and independent global action.

Obama's discourse on the alliance is not without boundaries, however. The president clearly distances himself from previous US administrations' approaches to NATO and takes his own attitude. His choice of words is strategic in nature, repeating reform and renewal to stress that it is time to end the status quo and move forward, substituting alliance with partnership to subject restructuring of the organization to a joint effort, and using modal verbs of obligation to make it clear that cooperation is not a matter of choice but of necessity. Consequently, it is not hard to define where, according to Obama, the border should be for the alliance, if it wants to become an international good for allies to inherit and a means to accomplish the task it is called upon to perform, rather than becoming a burden to carry and an impediment to development of productive mutual affairs.

\section{Conclusion}

From this analysis, three conclusions can be drawn. First, President Obama creates his own vocabulary of the alliance. Second, the rhetoric sets the course and defines the nature of his policies. Third, the policies demonstrate his political practice. Obama's rhetoric of the alliance defines NATO in terms of a relationship/a partnership. It restates allied values and tasks but reinvents the way to stay committed to them. It continues to appreciate allies' shared history but shifts on how present and future challenges should be confronted. It puts responsibilities first, balances interests, and leaves little room for negotiation. The working of the alliance within the president's rhetoric is suggestive of his motive. The proposed assumption is that Obama wants public opinion to share his view of the relationship in which all allies have a mission in the world. Positioning the obligation argument as the purpose behind the alliance's actions allows him to justify involvement in existing conflicts, manage disagreements about the necessity to carry out new engagements, and embrace the ambiguities in his own statements regarding why and how operations should be conducted.

Moreover, Obama's rhetoric of the alliance informs of his administration's course in transatlantic relations. While the president's presence at the celebration of the 60th anniversary of 
the establishment of NATO can be seen as a sign of the US support for the partnership, his rhetoric clearly makes this support conditional, in that it obliges allies on both sides of the Atlantic to work harder for their relationship: Europe to place higher priority on common purpose than individual interests and to look at American policies through the lens of benefits instead of risks and the US to attach more importance to allied cooperation and to show more respect for allies' policies. Rhetoric which goes beyond the niceties of diplomatic protocol and openly addresses core disagreements on critical issues signals that the administration is approaching the alliance in a very pragmatic manner.

In doing so, it is attempting to break the deadlock in transatlantic relations, one in which Europe does not block US war on terror policy but does not support it enough either; the US demands much from Europe in terms of assistance with war on terror challenges but implements policies that widen the divide between allies and keep them more isolated. In trying to narrow the differences, the president is convincing that preserving the transatlantic partnership in its current state is as unlikely as decoupling from it and pursuing a successful independent foreign policy course. Unlike allies driven by either sentiment or skepticism associated with the alliance's main focus and concerns, Obama is motivated by political reality. Deciding whether this motivation served him well is bound to take time and generate discussion. The ideographic analysis is part of this process and conversation, explaining how motives are developed and translated into action, and why this matters.

\section{References:}

Amernic, J. H., \& Craig, R. J. (2004). 9/11 in the Service of Corporate Rhetoric: Southwest Airlines' 2001 Letter to Shareholders. Journal of Communication Inquiry, 28(4), 325-41.

Bennett-Carpenter, B. (2009). The ideograph revisited: Political, cultural, specialized. Paper presented at the National Communication Association.

Bush, G. W. (2001a). Letter to Members of the Senate on the Kyoto Protocol on Climate Change. https://www.presidency.ucsb.edu/documents/letter-members-the-senate-the-kyoto-protocol-climate-change (15/11/2018).

Bush, G. W.(2001b). Remarks Announcing the United States Withdrawal from the Anti-Ballistic Missile Treaty. https://www.presidency.ucsb.edu/documents/remarks-announcing-the-united-states-withdrawal-from-the-antiballistic-missile-treaty $(15 / 11 / 2018)$.

Charland, M. (1987). Constitutive Rhetoric: The Case of the Peuple Quebecois. Quarterly Journal of Speech, 73(2), 133-50.

Cloud, D. L. (1998). The Rhetoric of Family Values: Scapegoating, Utopia, and the Privatization of Social Responsibility. Western Journal of Communication, 62, 4, 387-419.

Condit, C. M., \& Lucaites, J. L. (1993). Crafting Equality: America's Anglo-African Word. Chicago: University of Chicago Press. 
Coogan, D. (2002). Public Rhetoric and Public Safety at the Chicago Transit Authority: Three Approaches to Accident Analysis. Journal of Business and Technical Information, 16(3), 277-305.

CTBT Report. (2001). Final Declaration. Conference on Facilitating the Entry into Force of the Comprehensive Nuclear Test Ban Treaty, New York, November 11-13, 2001. Disarmament Diplomacy,61, http://www.acronym.org.uk/old/archive/dd/dd61/61app.htm (15/11/2018).

Delgado, F. P. (1995). Chicano Movement Rhetoric: An Ideographic Interpretation. Communication Quarterly, 43(4), 446-76.

Delgado, F. P. (1999). The Rhetoric of Fidel Castro: Ideographs in the Service of Revolutionaries. Howard Journal of Communication, 10(1), 1-14.

Edwards, J. L., \& Winkler, C. K. (1997). Representative form and the visual ideograph: The Iwo lima image in editorial cartoons. Quarterly Journal of Speech, 83(3), 289-310.

Feinstein, L., \& Lindberg, T. (2009). Means to an End. U.S. Interest in the International Criminal Court. Washington, D. C.: Brookings Institution Press.

Gallup. (2009). Gallup Daily: Obama Job Approval. https://news.gallup.com/poll/113980/Gallup-Daily-Obama-JobApproval.aspx (12/6/2019).

Grindstaff, D. (2003). Queering Marriage: An Ideographic Interrogation of Heteronormative Subjectivity. Journal of Homosexuality, 45(2), 257-75.

Hasian, M. Jr., Condit, C. M., \& Lucaites, J. L. (1996). The Rhetorical Boundaries of 'The Law': A Consideration of the Rhetorical Culture of Legal Practice and the Case of the 'Separate but Equal' Doctrine. Quarterly Journal of Speech, 82(4), 323-42.

Heindel, A. K. (2004). The Counterproductive Bush Administration Policy Toward the International Criminal Court. Seattle Journal for Social Justice, 2(2), 345-92.

Hodge, C. C. (2010). An ocean apart: The legacy of the Bush years in transatlantic security. Journal of Transatlantic Studies, 8(3), 279-89.

Jasinski, J. (2002). Puritans/Puritanism as Ideograph. The Review of Communication, 2, 90-96.

Johnson, D. (2007). Mapping the Meme: A Geographical Approach to Materialist Rhetorical Criticism. Communication and Critical/Cultural Studies, 4(1), 27-50.

Kupchan, C. A. (2012). A Still-Strong Alliance. Policy Review, https://www.hoover.org/research/still-strong-alliance $(15 / 11 / 2018)$.

Kuypers, J. A., \& Althouse, M. T. (2009). John Pym, Ideographs, and the Rhetoric of Opposition to the English Crown. Rhetoric Review, 28(3), 225-45.

Lee, R. (2009). Ideographic Criticism. In: J. A. Kuypers (ed.), Rhetorical Criticism. Perspectives in Action (pp. 285320). Lanham: Lexington Books.

Long, K. (2013). 'Terrorism' in the Age of Obama: The Rhetorical Evolution of President Obama's Discourse on the 'War on Terror.' Undergraduate Review, 9, 87-93.

McCann, B. J. (2007). Therapeutic and material 'victim'hood: ideology and the struggle for meaning in the Illinois death penalty controversy. Communication and Critical/Cultural Studies, 4, 382-401.

McGee, M. C. (199). The 'ideograph': A link between rhetoric and ideology. In J. R. Andrews (ed.), The Practice of Rhetorical Criticism (pp. 331-47). New York: Longman.

Miller, L. (1999). Public argument and legislative debate in the rhetorical construction of public policy: The case of Florida midwifery legislation. Quarterly Journal of Speech, 85(4), 361-79.

Obama, B. (2008a). Global Climate Summit. https://www.youtube.com/watch?v=X0fMr2iJR3M (15/11/2018).

Obama, B. (2008b). Missile Defense. https://www.youtube.com/watch?v=xD0Ln_6XBCk (15/11/2018). 


\section{Marta Rzepecka}

Obama, B. (2009a). Remarks at a Town Hall Meeting and a Question-and-Answer Session in Strasbourg. https://www.presidency.ucsb.edu/documents/remarks-town-hall-meeting-and-question-and-answer-sessionstrasbourg $(15 / 11 / 2018)$.

Obama, B. (2009b). Remarks in Prague. https://www.presidency.ucsb.edu/documents/remarks-prague (15/11/2018).

Obama, B. (2009c). Remarks to the North Atlantic Council in Strasbourg, France. https://www.presidency.ucsb.edu/documents/remarks-the-north-atlantic-council-strasbourg-france (15/11/2018).

Obama, B. (2009d). The President's News Conference in London. https://www.presidency.ucsb.edu/documents/thepresidents-news-conference-london (15/11/2018).

Obama, B. (2009e). The President's News Conference in Strasbourg. https://www.presidency.ucsb.edu/ documents/the-presidents-news-conference-strasbourg (15/11/2018).

Obama, B. (2009f). The President's News Conference with Chancellor Angela Merkel of Germany in Baden-Baden, Germany. $\quad$ https://www.presidency.ucsb.edu/documents/the-presidents-news-conference-with-chancellor-angelamerkel-germany-baden-baden-germany (15/11/2018).

Obama, B. (2009g). The President's News Conference with President Nicolas Sarkozy of France in Strasbourg,

France. $\quad$ https://www.presidency.ucsb.edu/documents/the-presidents-news-conference-with-president-nicolassarkozy-france-strasbourg-france (15/11/2018).

Obama, B. (2009h). The President's News Conference with Prime Minister Gordon Brown of the United Kingdom in London, England. https://www.presidency.ucsb.edu/documents/the-presidents-news-conference-with-primeminister-gordon-brown-the-untied-kingdom-london (15/11/2018).

Obama, B. (2009i). The President's Weekly Address.https://www.presidency.ucsb.edu/documents/the-presidentsweekly-address-143 (15/11/2018).

Obama, B. (2007). You Can Take That To The Bank. https://www.youtube.com/watch?v=8V1Xfs1K04g $(15 / 11 / 2018)$.

Palczewski, C. (2005). The male Madonna and the feminine Uncle Sam: Visual argument, icons, and ideographs in 1909 anti-woman suffrage postcards. Quarterly Journal of Speech, 91(4), 365-94.

Parry-Giles, T. (1995). Ideology and Poetics in Public Issue Construction: Thatcherism, Civil Liberties, and 'Terrorism.' Communication Quarterly, 43(2), 182-96.

Pew Research Center (2008). Optimism and Obstacles for Obama in Europe. https://www.pewresearch.org/global/ 2009/03/26/obama-abroad/ (12/6/2019).

Pew Research Center (2010). Obama More Popular Abroad Than At Home, Global Image of U.S. Continues to Benefit. https://www.pewresearch.org/global/2010/06/17/obama-more-popular-abroad-than-at-home/ (12/6/2019).

Polling Report (2016). President Obama and the Obama Administration. http://pollingreport.com/obama_ad.htm (12/6/2019).

Rielly, J. (2008). The Bush Administration's Foreign Policy Legacy. Politique américaine, 3(12), $73-86$.

The German Marshall Fund of the United States. (2008). Transatlantic Trends 2008. http://www.flad.pt/wpcontent/uploads/2014/05/livro09.pdf (12/6/2019).

Towner, E. B. (2010). A Patriotic Apologia: The Transcendence of the Dixie Chicks. Rhetoric Review, 29(3), 293309.

Valenzano III, J. M. (2006). Freedom and Terror: President George W. Bush's Ideograph Use during his First Term. Georgia State University, PhD dissertation.

Weitsman, P. A. (2004). Dangerous alliances: Proponents of peace, weapons of war. Palo Alto: Stanford University Press.

Winkler, C. (2006). In the Name of Terrorism: Presidents on Political Violence in the Post-World War II Era. Albany: State University of New York Press. 